спілкування залежить від вміння чітко та однозначно донести свою думку, почути співрозмовника та виробити стратегію прийняття рішення. Подальші дослідження даної теми дозволять ефективніше використовувати онлайн засоби для більш досконалого процесу вивчення української мови та спілкування у мистецькій сфері.

\title{
Література:
}

1. Основні принципи комунікації. Електронний ресурс. URL: https://stud.com.ua/27290/psihologiya/osnovni_printsipi_komunikatsiyi (дата звернення 13.03.2021)

DOI https://doi.org/10.30525/978-9934-26-073-5-1-17

\section{ОСОБЛИВОСТІ ВЕРБАЛІЗАЦІЇ КОНЦЕПТУ ПІЧ В УКРАЇНСЬКІЙ НАРОДНІЙ СЛОВЕСНОСТІ}

\author{
Хомік О. С. \\ кандидатка філологічних наук, \\ дочентка кафедри украӥнської мови \\ Харківського національного університету імені В. Н. Каразіна \\ м. Харків, Україна
}

В останні десятиліття термін «концепт» став одним із базових понять сучасної лінгвістики. Вивчення концептів національної культури, зокрема й концепту ПІЧ, на матеріалі фольклорних текстів на сьогодні $\epsilon$ особливо актуальним. Різноаспектним дослідженням означеного концепту займалися такі вітчизняні та зарубіжні науковці, як В. Кононенко [2],Н. Кринична [3], О. Масло [4], Л. Невська [5], А. Топорков [6], В. Усачова [12] та інші. Проте в сучасному мовознавстві досі бракує комплексної роботи, присвяченої вивченню семантики та функціонування концепту ПІЧ в українській усній народній словесності.

До аналізу ми залучили близько 200 одиниць фактичного матеріалу, вилученого із текстів різних жанрів української усної народної творчості, зокрема прислів 'їв, приказок, загадок, казок. Так, наприклад, дослідивши семантику та функціонування лексеми niч в українських прислів'ях, приказках, ми дійшли таких висновків: 1) піч уважається символом материнського начала: «Піч - мати» [9]; 2) є одним із найважливіших місць у хаті, сакральним предметом: «Піч в хаті - те саме, щео вівтар у иеркві [9]; «Сказав би, так піч у хаті»[9]; «Мовчи, бо піч у хаті» [9]; 
2) слугує місцем відпочинку: «Старому піч, як малому колиска» [9]; 3) указує рівень достатку; «Добра річ, що є в хаті піч» [9]; «Добре ся там пестити, де піч велика і є кому варити» [9]; "Ані печі, ані лави» [9]; 4) відбиває уявлення про вади людини: «Горе тому, що на печі: сюди пече, туди гаряче» [9]; «За ходячим ліс, за лежачим піч» [9].

В українській народній традиції поширені загадки 3 компонентом «піч». Так, наприклад, у загадках, де означена лексема зашифрована у відгадці, репрезентуються такі функції печі: 1) є місцем, на якому гріються: «Бабу гріє не кожух, а веселий теплий дух» [7, с. 43]; 2) сакральним місцем, межею між світом «своїм», людським, і «чужим», потойбічним: «Під землею рай кипить» [7, с. 43]; 3) ототожнюється із жіночим, материнським началом: «Бабуся біла, сива, Взимку всім мила. А як літо наступає, Бабусю забувають» [8, с. 44]. Зауважимо, що жінкабаба - це ключовий образ в обрядовості українців, адже вона $\epsilon$ господинею дому, піклується про добробут сім'ї, народжує дітей тощо $[1$, c. 54]. Епітети «біла», «сива» вказують на те, що піч завжди тримали в чистоті, білили та шанували, розмальовували квітами й ніколи не залишали пустою; 4) піч - місце, де спалюють старі речі: «Котра діра най послідня у плота?» [7, с. 43]; 5) приготування їжі: «Потрапило наше тісто У гаряче місие. Попало - не пропало, Рум'яної булкою стало» [8, с. 112]. Проте, за нашими спостереженнями, найбільша кількість аналізованих текстів пов'язана 3 образами тварин, зокрема коровою, конем, ведмедем: «Корова без ніг, без тіла, скирту соломи з їла» [8, с. 112]; «Біла кобила весь ліс переїла» [8 , с. 112]; «I не кінь, і не пес. Ïсть дрова, не овес» [7, с. 44];«Стоять коні на припоні. Ні п’ють, ні їдять I голодні не стоять» [7, с. 43]; «Хатня корова поїдає дрова і весь дім гріє» [8, с. 112]; «Сидить медвідь на яйиях» [8, с. 111]. Зауважимо, що корова в українській міфології - символ годувальниці, вона так само, як і піч, уважається символом добробуту $[1 ; 2]$. Кінь виступає посередником між світами, таку ж функцію виконує піч $[1 ; 2 ; 4]$. Прикметно, що одна з головних частин житла - пічний стовп - називається «коньовим» стовпом або просто «конем». Він мав безпосередню причетність до домашнього вогнища, отже й душ померлих предків, тобто слугував зв'язком між світами. Ведмідь в українській міфології $\epsilon$ символом багатства, родючості й достатку. Здавна вважається, що бурий ведмідь приніс народові вогонь [4, с. 6].

Основним атрибутом печі є вогонь, що підтримував тепло в оселі, допомагав приготувати їжу і мав чудодійну силу: «Червоне телятко Чорну корову лиже» [7, с. 45]; «Повна стайня червоних корів, Прийде до них віл чорний та вииткі корови розмече» [7, с. 44]. 
Проаналізувавши тексти казок, ми дійшли таких висновків: 1) піч $є$ одним із важливих складників концептуальної картини світу українців. Вона відіграє особливу роль у внутрішньому просторі будинку, поєднуючи в собі символіку центру. Як джерело їжі і домашнього вогню піч утілює ідею повноти і благополуччя будинку, що найповніше відбито в українських народних побутових казках: «Розкопав Іван те місие коло печі, а там - повний чавун золота. За то золото закупив він панський дім і всю мушію того пана» [11]. Пічна труба - специфічний вихід 3 дому, призначений в основному для контактів з іншим світом: через неї всередину проникають вогняний змій, а назовні вилітають відьма, душа померлого, хвороба. Така функція печі найкраще відбита в народних героїко-фантастичних казках. Часто піч слугувала локусом для ініціації неофітів: "Довго йшов і в хащі натрапив на хижку... - Hу, - думає собі, зайду я в ией двір. Отут мусить бути моя Ілонка. Зайшов до хижі й бачить: на печі сидить та сама баба, якій горнець розбив. Поклонився: Добрий день, бабко. - Добрий день, синку. Та ти й справді аж сюди придибав? - Айно. Дайте якусь службу. - Добре. Але спочатку залізай у піч ...» $[10$, c. 34].

Символічне значення приписувалося таким діям, як: заглядати в піч, закривати і відкривати піч або комин, доторкатися до печі або колупати ii, гріти в ній руки, грітися на/в ній.

Особливою символікою наділявся й простір біля печі: пічної стовп, пічне начиння (кочерга, рогач, хлібна лопата), посуд і домашне начиння (горщик, сковорода), пічна заслінка, вугілля, попіл і зола. У народному уявленні образ печі нерозривно пов'язаний із сімейним благополуччям, із шлюбними зв'язками і продовженням роду.

Піч була тим священним місцем, де жінка народжувала дитину. Водночас піч - це обитель старших членів родини. Символом єдності сонця і вогнища $€$ випічка в печі короваїв, що за формою нагадували сонце: «Так ото ішов одним селом подорожній. Уже заходила піч, $i$ він підійшов до крайньої хати. Бачить, на призьбі чоловік сидить» [11]. Сонце дає усьому живому тепло і світло. Так само, за віруваннями українців, піч $є$ джерелом життя, світла, тепла. Із нею пов'язані обряди «женити комина». Піч часто білили, прикрашали декоративними розписами, витинанками, розмальовками 3 паперу. Категорично заборонялося плювати у палаючий вогонь, лаятися біля печі («не при печі будь сказано»). Піч була оберегом від різної нечисті. Лучину, жаринки, попіл використовували при ворожіннях, лікуванні хворих.

Отже, розвідка є спробою осмислення семантики та функціонування концепту ПІЧ в українських прислів'ях, приказках, загадках, казках. 
Аналізований фактичний матеріал дає можливість виявити специфіку вербалізації досліджуваного концепту в українській усній народній творчості.

\section{Література:}

1. Войтович В. Українська міфологія. К. : Либідь, 2002. 664 с.

2. Кононенко О. А. Українська міфологія та культурна спадщина: міфол. уявлення, вірування, обряди, легенди та їхні відлуння у фольклорі і пізніших звичаях українців, братів-слов'ян та ін. народів. Харків : Фоліо, 2011. С. 498-499.

3. Криничная Н.А. Русская печь: структурные элементы в свете народных представлений. М. : Энциклопедия российских деревень, 2008. C. 206-210.

4. Масло О. Національно-культурний компонент у лексиці українських народних казок. Автореферат дисертації на здобуття ступ. канд. філол. наук: спец.10.02. 01 - українська мова. Х., 2008. 19 с.

5. Невская Л. Г. Печь в фольклорной картине мира // Исследования в области балто-славянской духовной культуры. Загадка как текст. М., 1999. С. 101-109.

6. Топорков А. Л. «Перепекание» детей в ритуалах и сказках восточных славян // Фольклор и этнографическая действительность. СПб., 1992. С. 114-118.

7. Українські народні загадки / упоряд. І. Гурин. Львів : Львівське книжково-журнальне видавництво, 1963. 91 с.

8. Українські народні загадки/ упоряд. М. Шестопал. Київ : Видавництво Академії Наук Української РСР, 1963. 398 с.

9. Українські приказки, прислів'я і таке інше. Збірники Опанаса Марковича і других/упоряд. М. Номис. Київ : Либідь, 1993. Режим доступу: https://chtyvo.org.ua > authors > Ukrainskyi_narod

10. Чарівна квітка: Українські народні казки з-над Дністра/ упоряд. М. А. Зінчук. Ужгород: Карпати, 1986. 301 с.

11. Українські народні казки Буковини [Електронний ресурс] / [упоряд. М. Зінчук]. Режим доступу до книги: http://proridne.org/ БУКОВИНА.html

12. Усачева В. В. Функции дома и его частей в лечебной магии// Славяноведение, 1996. № 5. С. 65-70. 